\title{
Genetic structure of populations
}

\section{POLYMORPHISM OF GROWTH HORMONE, GROWTH HORMONE RECEPTOR, PROLACTIN AND PROLACTIN RECEPTOR GENES IN CONNECTION WITH EGG PRODUCTION IN POLTAVA CLAY CHICKEN}

\section{R.A. KULIBABA}

State Poultry Research Station, National Academy of Agrarian Sciences of Ukraine, Borky, Zmiiv Region, Kharkiv Province, 63421 Ukraine, e-mail romankx@rambler.ru

Received June 16, 2014

\section{Abstract}

The molecular assisted selection in animals is based on polymorphism study of desired gene alleles related to economic important traits, particularly productivity parameters. Allelic variants can be a result of different modification of DNA nucleotide composition, i.e. spot mutations leading to a single nucleotide polymorphism (SNP), insertions and deletions (indel), etc. Anyway, targeted selection necessitates detecting gene polymorphism and estimating its relationship with productivity. The genes encoding proteins which are involved in the growth and development regulation, such as hormones, are considered the most perspective and attractive candidates. So far as the physiological effect of any hormone is known to be directly related to its receptor, it is advisable to study gene polymorphism of both hormones and their receptors. In the Ukraine the relationship between polymorphism of the genes mentioned hereinabove and hen performance was not still studied. Therefore these stipulate the relevance and novelty of our investigation presented in the paper. The genetic structure of Poltava Clay chicken egg-and-meat breed (line 14, $n=98$, laboratory population of State Poultry Research Station of the National Academy of Agrarian Sciences of Ukraine) was studied on growth hormone $(G H)$, growth hormone receptor $(G H R)$, prolactin $(P R L)$ and prolactin receptor genes $(P R L R)$. Gene polymorphism was determined by PCR-RFLP analysis and by comparative analysis of amplified fragment length when studying insertion in the prolactin locus. The growth hormone, growth hormone receptor and prolactin genes were polymorphic. The frequencies obtained were as follows: 0.372 and 0.628 for alleles $C$ and $T$ ( $P R L$-AluI), respectively, in $G H$ MspI (intron 1) 0.908 for alleles $A, 0.020$ for $B, 0.072$ for $C$; in $G H$-SacI (the intron 4) 0.036 for $A, 0.964$ for $B$; in $G H R$-NspI 0.280 for $A, 0.720$ for $B$. The prolactin gene ( 24 indel) and prolactin receptor gene were monomorphic. The relationship of different genotypes of prolactin, growth hormone, and growth hormone receptor genes with egg productivity was studied. All studied polymorphic loci were in Hardy-Weinberg equilibrium in population of Poltava clay chicken breed. It is shown the significant differences in the productivity of individuals of different genotypes for the loci of prolactin $(P R L$-AluI) and growth hormone $(G H$-SacI). The egg production for 12 weeks in the individuals with genotype $C C-P R L$ exceeded that in the individuals with genotype $T T-P R L$ and amounted to $75.38 \pm 2.33$ and $67.82 \pm 1.21$, respectively $(\mathrm{P}<0.01$ ). Egg production for 40 weeks in the chickens with genotype $C C-P R L$ reached $201.50 \pm 8.43$, and in $T T-P R L$ hens it was $188.32 \pm 3.45$. The egg weight at $30^{\text {th }}$ week of life was $54.80 \pm 1.44 \mathrm{~g}$ in the individuals with $C C-P R L$ genotype against $50.95 \pm 0.54 \mathrm{~g}$ in the individuals with $C T-P R L$ genotype $(\mathrm{P}<0.05)$. At the same time the heterozygous individuals with genotype $A B$ (SacI +/SacI-) on growth hormone gene were characterized by a significantly higher egg production during 12 week productive period compared to chickens with genotype $B B$ (SacI-/SacI-), particularly $72.00 \pm 1.67$ against $66.98 \pm 1.05$. Also the differences were shown in the egg weight at the $30^{\text {th }}$ week of life. Its value reached $55.02 \pm 1.52 \mathrm{~g}$ in the individuals with genotype $A B$ while in hens with genotype $B B$ it was $51.40 \pm 0.42 \mathrm{~g}(\mathrm{P}<0.05)$.

Keywords: PCR, polymorphism, egg production, growth hormone, prolactin, chicken.

Molecular genetic methods become increasingly common in the modern genetics of poultry. Being a kind of exotics until recently, molecular genetic markers have turned into an ordinary tool in genetic and breeding studies [1]. The widespread distribution of DNA technologies has made it possible to create the prerequisites for poultry breeding at a fundamentally new level, taking into account all opportunities which arise in direct handling with genetic material. 
The genomic breeding is based on the study of polymorphism of target genes, the allelic variants of which are associated with productive properties of animals. The allelic variants of functional genes are a result of different modifications of nucleotide composition, such as point mutations (Single Nucleotide Polymorphism - SNP), insertions/deletions (indel), etc. Anyway, polymorphism identification and subsequent study of its relationship with productivity characters provide a basis for further targeted breeding. All of the above is fully applicable to the poultry farming [1].

It is most interesting to search for polymorphism in the genes, the products of which are involved in regulation of various functions, primarily those associated with support of growth and differentiation [2]. Such objects include the genes encoding regulatory proteins, in particular, hormones. In turn, the physiological effect of any hormone directly depends on its receptor, therefore, it is reasonable to study the polymorphism of the genes encoding both hormones themselves and their receptors.

From this point of view in the poultry genetics, the genes of growth hormone, prolactin and their receptors are considered as one of the most promising candidate genes for studying the polymorphism and relationships of allelic variants with productive properties of poultry $[3,4]$.

Growth hormone and prolactin are referred to a class of peptide hormones with a wide spectrum of regulated functions [5]. Thus, growth hormone is directly involved in growth regulation and differentiation of various types of body tissues. At the same time, prolactin in birds takes part in reproductive cycle regulation as a specific initiator of brooding manifestation (increase in concentration of plasmatic prolactin leads to gradual decrease in egg-laying intensity and then to its complete cessation) [6, 7].

The growth hormone $(G H)$ gene, which is located in the chromosome 27, contains 5 exons and 4 introns with a total length equal to $\sim 4.35 \mathrm{kbp}$. It was shown that different SNP's (G662A, T3094C, C3199T, etc.) are present in various gene regions (introns, exons, etc.) [8]. The relationship between allelic variants and productivity characters (egg and meat productivity) was revealed [9]. Positive correlation of the SacI+ allele (intron 4) with indices of resistance to Marek's disease was noted, and, in turn, MspI polymorphism in the intron 1 is associated with egg productivity of poultry $[10,11]$.

The growth hormone receptor $(G H R)$ gene contains 10 exons and 9 introns with a total length equal to $\sim 130.33 \mathrm{kbp}$ and is located in the $\mathrm{Z}$ chromosome, which determines its hemizygous state in hen birds. It was shown that several different types of SNP's (G565A, A1512T, etc.) affecting the intronic and exonic parts, as well as nontranslated $5^{\prime}$ and $3^{\prime}$ gene regions, are present $[8$, $12,13]$. It was found that the allelic variants of the $G H R$ gene are associated with quality indices of shell and live weight, as well as with chicken dwarfism.

The prolactin $(P R L)$ gene includes 5 exons and 4 introns with a total length equal to $\sim 6.14 \mathrm{kbp}$ and is located in chromosome 2 . Polymorphism with regard to the presence of an insertion in a promoter gene region was shown along with several SNP's $[14,15]$. The relationship of different allelic variants of the prolactin gene with egg productivity for different chicken breeds, with brooding manifestation, etc. was revealed. For example, the presence of a 24-bp insertion positively correlates with increased egg-laying capacity and negatively correlates with brooding manifestation [16]. Cytosine transition into thymin at position -2402 in the prolactin gene was described, and positive correlation of egg-laying capacity with genotype CC was established [17]. In general, taking into account an important role of prolactin in poultry reproductive cycle regulation, we may note special opportunities for studying the polymorphism of this gene, first of all, in connection 
with egg-laying capacity [18].

The prolactin receptor $(P R L R)$ gene contains 12 exons and 11 introns (total length is $\sim 20.89$ thousand $\mathrm{bp}$ ) and is located in the $\mathrm{Z}$ chromosome as the growth hormone receptor gene. It was demonstrated that SNP's are present in various gene regions and are associated with productivity characters of chickens. Thus, the BamHI+ allelic variant by the exon 5 of the gene positively correlates with egg-laying capacity [3].

In Ukraine, the relationship between polymorphism of the mentioned genes and productive properties of domestic chicken breeds has not been studied yet, which largely determines the relevance and novelty of the performed study.

Based on the above, this study was aimed at investigating the genetic pattern of the Poltavskaya Glinistaya chicken breed population by the loci of growth hormone, growth hormone receptor, prolactin and prolactin receptor, as well as at identifying the relationship between the allelic variants of the listed genes and egg-laying capacity.

Technique. The studies were carried out using Poltavskaya Glinistaya poultry chickens, the egg-and-meat poultry bred in the Ukraine (line 14, $n=98$ ), which were kept at a laboratory vivarium at the experimental station. DNA was extracted from the blood samples taken from the comb onto sterile filter paper using a scarificator. Each sample was predried, marked and individually packed in order to prevent contamination. DNA extraction was carried out using a DNA-sorb-B commercial reagent kit (AmpliSens, Russia). The successful extraction of the DNA needed for analysis was assessed using electrophoresis in $0.7 \%$ agarose gel (CSLAG100, Cleaver Scientific, Great Britain) at $200 \mathrm{~V}$ within 5 min.

The prolactin gene was studied by two parameters, i.e. the presence of a $24 \mathrm{bp}$ insertion in a promoter gene region (24 indel) and single nucleotide polymorphism (cytosine transition into thymin) at position -2402 (C-2402T) (AluI restriction endonuclease). In the prolactin receptor gene, a BamHI polymorphism was assessed in the exon 5. As in case of prolactin, the growth hormone gene was investigated by two indicators, the MspI polymorphism in the intron 1 and SacI polymorphism in the intron 4. In the growth hormone receptor gene, cytosine transition into thymin was determined in the intron 5 (NspI restriction endonuclease).

The following nucleotide sequences of primers were used in amplification: 5'-TTTAA-TATTGGTGGGTGAAGAGACA-3' and 5'-ATGCCACTGATCCTCGAAAACTC-3' for $P R L$ (24 indel) [14]; 5'-AGAGGCAGCCCAGGCATTTTAC-3' and 5'-CCTGGGTCTGGTTTGGAA-ATT-3' for PRL (C2402T) [14]; 5'-ATCC-CCAGGCAAACATCCTC-3' and 5'-CCTCGACATCCAGCTCACAT-3' for $G H$ (intron 1) [19]; 5'-CTAAAGGACCTGGAAGAAGGG-3' and 5'-AACTTGTC-GTAGGTGGGTCTG-3' for $G H$ (intron 4) [11]; 5'TTGTCTGCTTTGATTCATTTCC-3' and 5'-TGCATTTCATTCTTCCCTTTTT- ${ }^{\prime}$ for PRLR (exon 5) [3]; 5'-ACGAAAAGTGTTTCAGTGTTGA-3' and 5'-TTTATCCCGTGTTCTCTTGACA-3' for GHR (intron 5) [20].

The PCR was carried out using DreamTaq PCR Master Mix reagents (Thermo Scientific, USA) in a Tertsik programmable thermocycler (DNATechnology, Russia) in accordance with the corresponding programs: denaturation for $5 \mathrm{~min}$ at $94{ }^{\circ} \mathrm{C}$; denaturation for $45 \mathrm{~s}$ at $94{ }^{\circ} \mathrm{C}$, annealing for $45 \mathrm{~s}$ at $54{ }^{\circ} \mathrm{C}$ for $P R L$ (24 indel), $62{ }^{\circ} \mathrm{C}$ for $P R L\left(\mathrm{C}-2402 \mathrm{~T}\right.$ ), $56{ }^{\circ} \mathrm{C}$ for $P R L R$ (exon 5) and $G H$ (intron 4), $55{ }^{\circ} \mathrm{C}$ for $G H$ (intron 1) and $60{ }^{\circ} \mathrm{C}$ for $G H R$ (intron 5), and elongation for $60 \mathrm{~s}$ at $72{ }^{\circ} \mathrm{C}$ ( 35 cycles); final elongation for $10 \mathrm{~min}$ at $72{ }^{\circ} \mathrm{C}$. The volume of reaction mixture was $20 \mu \mathrm{l}$; primer concentration for each locus was $0.2 \mu \mathrm{M}$.

The amplified fragments were treated with restriction endonucleases ac- 
cording to the attached instructions (FastDigest, Thermo Scientific, USA). Restriction products were separated in $1.5 \%$ agarose gel (CSL-AG100, Cleaver Scientific, Great Britain) at $150 \mathrm{~V}$ within $40 \mathrm{~min}$. Visualization was carried out using ethidium bromide in UV light. The size of restriction fragments was determined using M-50 and M-100 molecular weight markers (IzoGen, Russia).

For genotyping of individuals, restriction fragment lengths were compared on electrophoretograms for each locus.

The obtained results were used for calculation of the following parameters: actual (O) and theoretical (E) genotype distribution, genotype and allele frequencies, correspondence to Hardy-Weinberg genetic equilibrium of the population using the $\chi^{2}$ method, actual $\left(\mathrm{H}_{\mathrm{o}}\right)$ and theoretical $\left(\mathrm{H}_{\mathrm{e}}\right)$ heterozygosity, total number of alleles $(\mathrm{Na})$, effective number of alleles $\left(\mathrm{n}_{\mathrm{e}}\right)$, and Wright fixation index (Fis) in compliance with common methods [21]. The egg productivity indices were also taken into account, particularly the egg number $E_{12}$ and $E_{40}$ for 12 and 40 weeks of productive period, respectively, and the egg weight $\mathrm{Ew}_{30}$ and $\mathrm{Ew}_{52}$ at the age of 30 and 52 weeks, respectively.

The significance of differences was determined using Student's $t$-test [22].

Results. It is known that in the $P R L$ locus (24 indel) the allele $I$ contains a 24 bp insertion, whereas allele $D$ does not contain it. Genotype $I I$ is represented on an electrophoretogram by a $154 \mathrm{bp}$ fragment, while for $D D$ its length is $130 \mathrm{bp}$, and for $I D$ there are 130 and $154 \mathrm{bp}$ fragments. In case of $P R L$ (C-2402T), allele $C$ has three restriction sites for AluI (two monomorphic and one polymorphic), and allele $T$ has two sites. Therefore, genotype $C C$ is represented on an electrophoretogram by a set of fragments with the size of 160,144 , 81 and $54 \mathrm{bp}$; for $T T$ there are 304, 81 and $54 \mathrm{bp}$ fragments; and for $C T$ the 304, $160,144,81$ and $54 \mathrm{bp}$ fragment set is observed. The presence of a certain allele is determined by the presence of cytosine or thymin at a restriction site. Three alleles are possible for the $G H$ gene (intron 1). Allele $A$ is characterized by one restriction site, and for alleles $B$ and $C$ two and three sites are characteristic, respectively. Genotype $A A$ is represented on an electrophoretogram by fragments with the size of 539 and $237 \mathrm{bp}$, there are 392, 237 and $147 \mathrm{bp}$ fragments for $B B$, 267, 237, 147 and 125 bp fragments for $C C, 539,392,237$ and 147 bp fragments for $A B, 539,267,237,147$ and 125 bp fragments for $A C$, and 392, 267, 237, 147 and $125 \mathrm{bp}$ fragments for $B C$. The $G H$ gene (intron 4) exists in the form of two alleles, the $A$ and $B$. Allele $A$ carries two restriction sites for SacI (polymorphic and monomorphic sites), while allele $B$ has one monomorphic site. Genotype $A A$ is represented by restriction fragments with the size of 584, 440 and $144 \mathrm{bp}$; and they sized 1024 and $144 \mathrm{bp}$ in $B B$, and 1024, 584, 440 and 144 bp in $A B$. PRLR (exon 5) has only allele $A$ which contains one restriction site for BamHI, and allele $B$ without this site. Genotype $A O$ is represented on an electrophoretogram by fragments with the size of 195 and $55 \mathrm{bp}$, while in $B 0$ there is a fragment of $250 \mathrm{bp}$. The $G H R$ gene (intron 5) has allele $B$ with one restriction site for NspI and allele $A$ without this site. Genotype $A O$ is represented on an electrophoretogram by a $750 \mathrm{bp}$ fragment, and $B O$ has 200 and $550 \mathrm{bp}$ fragments.

The undertaken studies of the Poltavskaya Glinistaya chicken breed population have demonstrated that the loci of the genes of growth hormone (by the introns 1 and 4), growth hormone receptor and prolactin (C-2402T) are polymorphic, whereas the 24 indel and prolactin receptor gene are monomorphic (Fig.).

In case of 24 indel in the Poltavskaya Glinistaya chicken breed population, we observed individuals with only one genotype $D D$ (i.e. the prolactin locus is monomorphic with regard to the presence of the insertion in the promoter re- 
gion of the gene). Due to the monomorphic nature of this locus, the chickens of the analyzed line differ markedly from the previously studied individuals from populations of the Borkovskaya Barvistaya and Bely Plimutrok breeds [23].
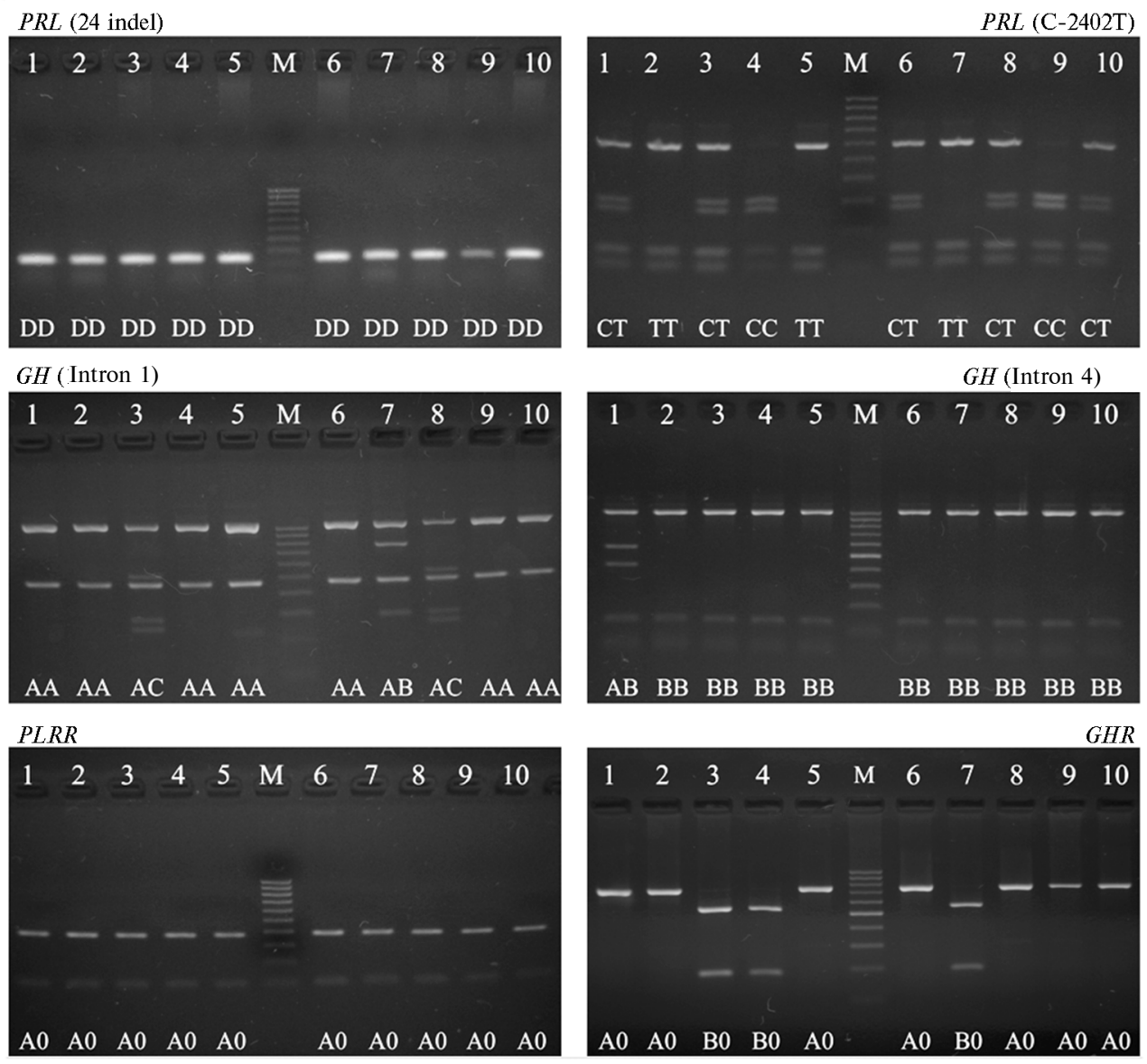

The electrophoretogram of the products of 24 indel $P R L$ prolactin gene promoter region amplification and products of restriction of C-2402T PRL prolactin gene fragment, the intron 1 of the $G H$ growth hormone gene, the intron 4 of the $G H$ growth hormone gene, the exon 5 of the $P R L R$ prolactin receptor gene and the intron 5 of the $G H R$ growth hormone receptor gene in the population of the Poltavskaya Glinistaya chicken breed: $1-10$ - well numbers; $\mathrm{M}-$ molecular weight marker (M-50, M-100, IzoGen, Russia); II, ID, DD, CC, CT, TT, $A A, A B, A C$, $B B, A 0, B O-$ the genotypes (the vivarium of the State Poultry Experimental Station of the National Academy of Agrarian Sciences of Ukraine, Kharkov Region, 2013).

Based on the presence of single nucleotide polymorphism at position -2402 of the prolactin gene, we identified individuals of all the three possible genotypes in the population (see Fig.).

According to the results of assessment of MspI polymorphism in the intron 1 of the growth hormone gene, there were individuals of three of six possible genotypes, $A A, A B$ and $\mathrm{AC}$, in the studied chicken population. No individuals homozygous by alleles $B$ and $C$ were found. Also, there were no individuals with genotype $B C$ in the studied population.

In turn, with regard to SacI polymorphism in the intron 4 of the growth hormone gene, individuals of two genotypes were found, i.e. $A B$ (SacI+/SacI-) and $B B$ (SacI-/SacI-). We did not identify individuals with genotype $A A$ $(\mathrm{SacI}+/ \mathrm{SacI}+)$ in the studied population.

In the studied chickens, the encoding prolactin receptor was represented 
by $A O$ variant (BamHI polymorphism in the exon 5). As in case of the prolactin gene (24 indel), it turned out to be monomorphic.

With regard to the $G H R$ gene, there were individuals of two genotypes, $A O$ and $B 0$, in the population. Due to hemizygosity of loci by the PRLR and $G H R$ genes in hen birds, no heterozygotes were found in the population in both cases (see Fig.)

The analysis of actual and theoretical distributions of individuals with different genotypes (for all the loci studied) did not reveal any disturbance of genetic equilibrium in the experimental chicken population, which indicates the absence of selection pressure.

As compared to populations of other Ukrainian chicken breeds (Bely Plimutrok, Borkovskaya Barvistaya) [23], the population we studied had a number of essential specific features. Thus, for the PRL locus, egg production chickens (Borkovskaya Barvistaya) and egg and meat production chickens (Bely Plimutrok) are characterized by high frequency of allele $I$ (contains an insertion) and allele $D$ (without an insertion), respectively, whereas the mentioned locus in the Poltavskaya Glinistaya chicken breed population was monomorphic at all (Table 1).

1. The frequency of genotypes and alleles of the prolactin $(P R L)$, prolactin receptor $(P R L R)$, growth hormone $(G H)$ and growth hormone receptor $(G H R)$ genes in the Poltavskaya Glinistaya chicken breed population (the vivarium of the State Poultry Experimental Station of the National Academy of Agrarian Sciences of Ukraine, Kharkov Region, 2013)

\begin{tabular}{|c|c|c|}
\hline Locus & Genotype (its frequency) & Allele (its frequency) \\
\hline$P R L$ (24 indel) & $D D(1)$ & $D(1)$ \\
\hline$P R L(\mathrm{C}-2402 \mathrm{~T})$ & $C C(0.110) ; C T(0.520) ; T T(0.370)$ & $C(0.372) ; T(0.628)$ \\
\hline$P R L R$ (exon 5) & $A O(1)$ & $A(1)$ \\
\hline$G H$ (intron 1 ) & $A A(0.820) ; A B(0.040) ; A C(0.140)$ & $A(0.908) ; B(0.020) ; \mathrm{C}(0.072)$ \\
\hline GH (intron 4) & $A B(0.070) ; B B(0.930)$ & $A(0.036) ; B(0.964)$ \\
\hline GHR (intron 5) & $\mathrm{A} 0(0.280) ; \mathrm{BO}(0.720)$ & $A(0.280) ; B(0.720)$ \\
\hline \multicolumn{3}{|c|}{$\begin{array}{l}\text { N o t e : The results were obtained using the PCR-RFLP (Restriction Fragment Length Polymorphism) analysis } \\
\text { and by the comparative analysis of amplified fragment lengths in studying the insertion in the prolactin locus. Re- } \\
\text { fer to the body of the article for allele and genotype description. }\end{array}$} \\
\hline
\end{tabular}

The analysis of MspI polymorphism in the intron 1 of the growth hormone gene revealed allele $C$ in the heterozygous state $(A C)$ in the studied chicken population, and its frequency was equal to 0.072 . Note the interesting fact that, according to the specialist literature, allele $C$ itself is almost completely absent in commercial line populations, but present in some native breeds (19). At the same time, as in this study, allele $C$ was found in populations of other Ukrainian chicken breeds (Borkovskaya Barvistaya and Bely Plimutrok) where its frequency was equal to 0.17 [23].

2. The population genetic characteristics of the Poltavskaya Glinistaya chicken breed with regard to the studied loci (the vivarium of the State Poultry Experimental Station of the National Academy of Agrarian Sciences of Ukraine, Kharkov Region, 2013)

\begin{tabular}{l|c|c|c|c|c}
\hline \multicolumn{1}{c}{ Gene locus } & $\mathrm{Na}$ & $\mathrm{H}_{\mathrm{O}}$ & $\mathrm{H}_{\mathrm{e}}$ & Fis & $\mathrm{n}_{\mathrm{e}}$ \\
\hline PRL (24 indel) & 1 & - & - & - & - \\
PRL (C-2402T, AluI) & 2 & 0.520 & 0.467 & -0.113 & 1.876 \\
$G H$ (intron 1, MspI) & 3 & 0.184 & 0.170 & -0.082 & 1.205 \\
GH (intron 4, SacI) & 2 & 0.071 & 0.069 & -0.029 & 1.074 \\
$P R L R$ (exon 5, BamHI) & 1 & - & - & - & - \\
GHR (NspI) & 2 & - & - & - & - \\
\hline
\end{tabular}

Note : Na is a total number of alleles; $\mathrm{H}_{\mathrm{o}}$ and $\mathrm{H}_{\mathrm{e}}$ are an actual and theoretical heterozygosity, respectively; Fis is Wright fixation index; $n_{\mathrm{e}}$ is an effective number of alleles. Dash means that an index cannot be calculated due to monomorphism of loci (PRL 24 indel and $P R L R)$ and hemizygosity $(G H R)$. The results were obtained using the PCR-RFLP (Restriction Fragment Length Polymorphism) analysis and by the comparative analysis of amplified fragment lengths in studying the insertion in the prolactin locus. 
In general, the analysis of the observed and expected genotype distributions within a sample showed that there was some kurtosis of heterozygotes by the loci of PRL (C-2402T) and $G H$ (intron 1) (Table 2). However, with regard to the $G H$ locus (intron 4), the indices reflecting the actual and theoretical heterozygosity were almost the same ( 0.071 and 0.069 , respectively).

Among polymorphic loci, the largest effective number of alleles was observed with regard to the prolactin gene $(C-2402 T)\left(n_{e}=1.876\right)$, and the least number $\left(\mathrm{n}_{\mathrm{e}}=1.074\right)$ was noted for the growth hormone gene (SacI polymorphism). Thus, the prolactin locus (C-2402T) had the highest polymorphism level among all the genes studied.

Along with the genetic population studies, we have assessed the egg productivity of chickens with different genotypes.

3. The productivity characters in chickens of the Poltavskaya Glinistaya breed with different allelic variants of the prolactin $(P R L)$, growth hormone $(G H)$ and growth hormone receptor $(G H R)$ genes (the vivarium of the State Poultry Experimental Station of the National Academy of Agrarian Sciences of Ukraine, Kharkov Region, 2013)

\begin{tabular}{|c|c|c|c|c|}
\hline \multirow{2}{*}{ Genotype } & \multicolumn{4}{|c|}{ Productivity character } \\
\hline & $\mathrm{En}_{12}, \mathrm{pcs}$ & $\mathrm{En}_{40}, \mathrm{pcs}$ & $\mathrm{Ew}_{30}, \mathrm{~g}$ & $\mathrm{Ew}_{52}, \mathrm{~g}$ \\
\hline \multicolumn{5}{|c|}{$P R L$} \\
\hline$C C$ & $75.38 \pm 2.33^{* *}$ & $201.50 \pm 8.43$ & $54.80 \pm 1.44^{*}$ & $58.57 \pm 1.86$ \\
\hline$C T$ & $67.04 \pm 1.34^{* *}$ & $192.29 \pm 3.09$ & $50.95 \pm 0.54^{*}$ & $57.46 \pm 0.60$ \\
\hline$T T$ & $67.82 \pm 1.21^{* *}$ & $188.32 \pm 3.45$ & $52.25 \pm 0.65$ & $59.50 \pm 0.82$ \\
\hline \multicolumn{5}{|c|}{$G H(\mathrm{MspI})$} \\
\hline$A A$ & $67.53 \pm 1.05$ & $191.01 \pm 2.65$ & $51.63 \pm 0.42$ & $58.34 \pm 0.57$ \\
\hline$A B$ & $66.50 \pm 3.62$ & $181.79 \pm 8.57$ & $51.08 \pm 2.81$ & $58.93 \pm 2.91$ \\
\hline$A C$ & $63.00 \pm 4.40$ & $171.50 \pm 26.05$ & $51.27 \pm 2.34$ & $58.94 \pm 1.33$ \\
\hline \multicolumn{5}{|c|}{$G H(\mathrm{SacI})$} \\
\hline$A B$ & $72.00 \pm 1.67^{*}$ & $199.00 \pm 10.13$ & $55.02 \pm 1.52^{*}$ & $58.80 \pm 1.13$ \\
\hline$B B$ & $66.98 \pm 1.05^{*}$ & $187.56 \pm 2.83$ & $51.40 \pm 0.42^{*}$ & $58.42 \pm 0.53$ \\
\hline \multicolumn{5}{|c|}{ GHR } \\
\hline$A 0$ & $65.58 \pm 2.38$ & $186.91 \pm 6.36$ & $52.28 \pm 0.99$ & $58.35 \pm 0.76$ \\
\hline BO & $68.67 \pm 0.87$ & $189.67 \pm 2.99$ & $51.46 \pm 0.48$ & $57.48 \pm 1.21$ \\
\hline \multicolumn{5}{|c|}{$\begin{array}{l}\text { Note : } E_{12} \text { and } E n_{40} \text { are the number of eggs for } 12 \text { and } 40 \text { weeks of productive period, respectively; } E_{30} \text { and } \\
\text { Ew } 52 \text { are the egg weight on the week } 30 \text { and the week } 52 \text { weeks of life, respectively; MspI, SacI are restriction en- } \\
\text { donucleases. Refer to the body of the article for genotype description by allelic variants. } \\
*^{* *} \text { The significance of differences is } \mathrm{P}<0.05 \text { and } \mathrm{P}<0.01 \text {, respectively. }\end{array}$} \\
\hline
\end{tabular}

Due to the monomorphic nature of the prolactin gene with regard to the presence of the insertion in the promoter region, it was impossible to study the relationship between allelic variants and productivity characters in chickens of the Poltavskaya Glinistaya breed. At the same time, the presence of single nucleotide polymorphism in the PRL locus (C-2402T) has allowed us to demonstrate that egg productivity for 12 weeks for individuals with genotype $C C-P R L$ exceeded that for chickens with genotype $T T-P R L$ and was equal to $75.38 \pm 2.33$ and $67.82 \pm 1.21 \mathrm{pcs}$, respectively $(\mathrm{P}<0.01)$ (Table 3$)$. Egg productivity for 40 weeks for chickens with genotypes $C C$-PRL and TT-PRL was equal to $201.50 \pm 8.43$ and $188.32 \pm 3.45$ pcs, respectively; these differences were unreliable, which was largely associated with small number of individuals with genotype $C C-P R L$ (11 chickens) as compared to TT-PRL (36 chickens). The data on positive correlation of genotype $C C$ - $P R L$ with egg productivity for chickens of the Poltavskaya Glinistaya breed are consistent with the results obtained for foreign chicken breeds [14, 17].

We also noted differences in egg weight on the $30^{\text {th }}$ week of life, particlularly $54.80 \pm 1.44 \mathrm{~g}$ for individuals with genotype $C C-P R L$ versus $50.95 \pm 0.54 \mathrm{~g}$ for chickens with genotype CT-PRL $(\mathrm{P}<0.05)$ (see Table 3$)$.

With regard to the $G H$ locus (MspI polymorphism in the intron 1), no significant differences in productivity indices were found between individuals of 
different genotypes, which is probably associated with the absence of chickens with genotypes $B B-G H$ and $C C-G H$ in the population (we compared the productivity of the individuals homozygous and heterozygous by allele $A$ ) (see Table 3).

At the same time, we have demonstrated the differences in egg productivity between individuals with different genotypes due to SacI polymorphism of the $G H$ gene. Thus, heterozygous individuals with genotype $A B(\mathrm{SacI}+/ \mathrm{SacI}-)$ were characterized by greater egg productivity than chickens with genotype $B B$ (SacI-/SacI-). A tendency towards higher indices of heterozygous individuals as compared to homozygous ones was also noted in case of egg weight in the $30^{\text {th }}$ week of life (see Table 3). With regard to the GHR locus, we have not found any significant differences in egg productivity indices. The locus of $P R L R$, as well as that of prolactin (with regard to the presence of the insertion in the promoter region), turned out to be monomorphic, which made it impossible to study the relationship between the genotype and productivity characters of chickens.

So, we have investigated the genetic pattern of the Poltavskaya Glinistaya chicken breed population by the loci of the growth hormone, growth hormone receptor, prolactin and prolactin receptor genes. It was demonstrated that the growth hormone, growth hormone receptor and prolactin genes were polymorphic in the experimental population of chickens. With regard to all the polymorphic loci studied, the Poltavskaya Glinistaya chicken breed population is in the state of Hardy-Weinberg genetic equilibrium. The prolactin (with regard to the presence of the insertion in the promoter region) and prolactin receptor genes are monomorphic. We have demonstrated positive correlation of genotypes in respect to prolactin $(C C-P R L)$ and growth hormone $(A B-G H)(\mathrm{SacI}+/ \mathrm{SacI}-)$ with egg number for 12 weeks of productive period and egg weight on the $30^{\text {th }}$ week of life. The obtained data can be further used in targeted breeding of Poltavskaya Glinistaya chickens in order to get offsprings from desirable genotypes, which, in combination with classical breeding methods, will make it possible to unlock the productive potential of poultry to a maximum effect.

\section{REFERENCES}

1. Fulto n J.E. Molecular genetics in a modern poultry breeding organization. World's Poultry Sci. J., 2008, 64: 171-176 (doi: 10.1017/S0043933907001778).

2. Enay ati B., Rahimi-Mianji G. Genomic growth hormone, growth hormone receptor and transforming growth factor $\beta-3$ gene polymorphism in breeder hens of Mazandaran native fowls. African J. Biotechnol., 2009, 8(14): 3154-3159.

3. Rashidi H., Rahimi-Mianji G., Farhadi A., Gholizadeh M. Association of prolactin and prolactin receptor gene polymorphisms with economic traits in breeder hens of indigenous chickens of Mazandaran province. Iranian J. Biotechnol., 2012, 10(2): 129-135.

4. Nie Q., Sun B., Zhang D., Luo C., Ishag N.A., Le i M., Yang G., Zhang X. High diversity of the chicken growth hormone gene and effects on growth and carcass traits. $J$. Hered., 2005, 96(6): 698-703 (doi: 10.1093/jhered/esi114).

5. Kansaku N., Hiyama G., S as a nami T., Zadworny D. Prolactin and growth hormone in birds: protein structure, gene structure and genetic variation. The Journal of Poultry Science, 2008, 45: 1-6 (doi: 10.2141/jpsa.45.1).

6. El H al aw a ni M.E., Silsby J.L., B e hnke E.J. Fe hrer S.C. Hormonal induction of incubation behavior in ovarioectomized female turkeys (Meleagris gallopavo). Biol. Reprod., 1986, 35: 59-67 (doi: 10.1095/biolreprod35.1.59).

7. R e d d y I.J., D avid C.G., R a ju S.S. Chemical control of prolactin secretion and it's effect on pause days, egg production and steroid hormone concentration in Girirani birds. Int. J. Poult. Sci., 2006, 5(7): 685-692 (doi: 10.3923/ijps.2006.685.692).

8. Nie Q., Lei M., Ouyang J., Zeng H., Yang G., Zhang X. Identification and characterization of single nucleotide polymorphisms in 12 chicken growth-correlated genes by denaturing high performance liquid chromatography. Genet. Sel. Evol., 2005, 37: 339-360 (doi: 10.1051/gse:2005005)

9. Nie Q., Ip S.C.Y., Zhang X., Leung F.C., Yang G. New variations in intron 4 of 
growth hormone gene in Chinese native chickens. J. Hered., 2002, 93(4): 277-279 (doi: 10.1093/jhered/93.4.277).

10. Liu H., Kung H., Fulton J., Morgan R.W., Cheng H.H. Growth hormone interacts with the Marek's disease virus SORF2 protein and is associated with disease resistance in chicken. PNAS USA, 2001, 98(16): 9203-9208 (doi: 10.1073/pnas.161466898).

11. Feng X.P., Kuhnlein U., Aggrey S.E., Gavora J.S., Zadworny D. Trait association of genetic markers in the growth hormone and the growth hormone receptor gene in a white leghorn strain. Poult. Sci., 1997, 76: 1770-1775 (doi: 10.1093/ps/76.12.1770).

12. Khoa D., Khang N., Ngu N., Matey J., Loan H.T.P., Thuy N.T.D. Single nucleotide polymorphisms in GH, GHR, GHSR and insulin candidate genes in chicken breeds of Vietnam. Greener Journal of Agricultural Science, 2013, 3(10): 716-724.

13. Ouyang J.H., Xie L., Nie Q., Luo C., Liang Y., Zeng H., Zhang X. Single nucleotide polymorphism (SNP) at the GHR gene and its associations with chicken growth and deposition traits. Br. Poultry Sci., 2008, 49(2): 87-95 (doi: 10.1080/00071660801938817).

14. Cu i J.-X., Du H.-L., Li ang Y., D eng X.-M., Li N., Zhang X.-Q. Association of polymorphisms in the promoter region of chicken prolactin with egg production. Poult. Sci., 2006, 85: 26-31 (doi: 10.1093/ps/85.1.26).

15. Ji a ng R.-S., Xu G.-Y., Z h a ng X.-Q., L e ung F.C.C., Z h a ng X. Polymorphisms of 5' flanking region of chicken prolactin gene. Domestic Animal Endocrinology, 2006, 30: 1-16 (doi: 10.1016/j.domaniend.2005.05.006).

16. Jiang R.-S., Xu G.-Y., Zhang X.-Q., Yang N. Association of polymorphisms for prolactin and prolactin receptor genes with broody traits in chickens. Poultry Sci., 2005, 84: 839-845 (doi: 10.1093/ps/84.6.839).

17. Bagheri Sarvestani A.S., Niazi A., Zamiri M.J., Dadpasand Taromsari M. Polymorphisms of prolactin gene in a native chicken population and its association with egg production. Iranian J. Vet. Res., 2013, 14(2): 113-119.

18. Alipanah M., Shojai an K., B a nd a ni H.K. The polymorphism of prolactin gene native chicken Zabol region. J. Anim. Vet. Adv., 2010, 9(24): 3005-3007 (doi: 10.3923/javaa.2011.619.621).

19. I p S.C.Y., Zhang X., Le ung F.C. Genomic growth hormone gene polymorphisms in native Chinese chickens. Exp. Biol. Med., 2001, 226(5): 458-462.

20. Li H., Zhu W., Che n K., Wu X., T ang Q., G a o Y. Associations between GHR and IGF-1 gene polymorphisms, and reproductive traits in Wenchang chickens. Turk. J. Vet. Anim. Sci., 2008, 32(4): 281-285 (doi: 10.3923/rjpscience.2010.19.22).

21. M e r k u r'e v a E.K. Geneticheskie osnovy selektsii v skotovodstve [Genetic bases for livestock breeding]. Moscow, 1977.

22. Merkur'eva E.K. Biometriya $v$ selektsii $i$ genetike sel'skokhozyaistvennykh zhivotnykh [Biometry in genetics and breeding farm animals]. Moscow, 1970.

23. Kulibaba R.A., Podstreshnyi A.P. Tsitologiya $i$ genetika, 2012, 6: 75-82 (doi: $10.3103 /$ S0095452712060060). 